\title{
Positron emission tomography to visualise in-situ microbial metabolism in natural sediments
}

DOI:

10.1016/j.apradiso.2018.11.005

\section{Document Version}

Accepted author manuscript

Link to publication record in Manchester Research Explorer

\section{Citation for published version (APA):}

Thorpe, C. L., Williams, H. A., Boothman, C., Lloyd, J. R., \& Morris, K. (2018). Positron emission tomography to visualise in-situ microbial metabolism in natural sediments. Applied Radiation and Isotopes.

https://doi.org/10.1016/j.apradiso.2018.11.005

\section{Published in:}

Applied Radiation and Isotopes

\section{Citing this paper}

Please note that where the full-text provided on Manchester Research Explorer is the Author Accepted Manuscript or Proof version this may differ from the final Published version. If citing, it is advised that you check and use the publisher's definitive version.

\section{General rights}

Copyright and moral rights for the publications made accessible in the Research Explorer are retained by the authors and/or other copyright owners and it is a condition of accessing publications that users recognise and abide by the legal requirements associated with these rights.

\section{Takedown policy}

If you believe that this document breaches copyright please refer to the University of Manchester's Takedown Procedures [http://man.ac.uk/04Y6Bo] or contact uml.scholarlycommunications@manchester.ac.uk providing relevant details, so we can investigate your claim.

\section{OPEN ACCESS}




\title{
Positron emission tomography to visualise in-situ microbial metabolism in natural sediments
}

\author{
Clare L. Thorpe ${ }^{1}$, Heather A. Williams ${ }^{2}$, Christopher Boothman ${ }^{1}$, Jonathan R. Lloyd ${ }^{1}$ \\ and Katherine Morris ${ }^{1}$
}

${ }^{1}$ Research Centre for Radwaste Disposal and Williamson Research Centre for Molecular Environmental Science, School of Earth and Environmental Sciences, The University of Manchester, Manchester, M13 9PL, UK.

${ }^{2}$ Nuclear Medicine Centre, Manchester Royal Infirmary, Manchester, M13 9WL, UK.

* Corresponding author: clarelthorpe@gmail.com

\begin{abstract}
Positron Emission Tomography simultaneously monitored flow dynamics and in-situ microbial activity in opaque sediment columns. An ${ }^{18} \mathrm{~F}$ labelled electron donor, 2-deoxy-2$\left[{ }^{18} \mathrm{~F}\right]$-fluoro-D-glucose $\left({ }^{18} \mathrm{FDG}\right)$, was added to flowing columns containing sterile sediment, microbially active sediment and quartz sand. ${ }^{18}$ FDG accumulated in microbially active, glucose primed, sediment $\left(10^{5}-10^{6}\right.$ cells $\left.\mathrm{g}^{-1}\right)$ at $10^{-16} \mathrm{~mol} \mathrm{~g}^{-1}(\sim 40 \%$ of the $100 \mathrm{MBq}$ spike) giving the first example of ${ }^{18}$ FDG uptake by indigenous microorganisms in a complex sediment system at flow rates representative of the shallow subsurface.
\end{abstract}

\section{Key words}

PET, ${ }^{18}$ FDG, microorganisms, sediment columns

\section{Introduction}

Positron Emission Tomography (PET) is a non-destructive method of imaging which can be used to study fluid transport through porous media. PET scanners consist of a cylinder of 
scintillation detectors coupled to fast electronics, feeding into software which generates a three-dimensional image mapping the distribution of a positron-emitting radionuclide. The detectors collect coincident pairs of $511 \mathrm{keV}$ gamma rays emitted at $180^{\circ}$, which originate from the site where a positron produced by radioactive decay annihilates with an electron in the surrounding material. PET is an ultra-sensitive technique allowing detection of very low concentrations of radiotracer $\left(<10^{-16} \mathrm{M}\right.$ : $\left.10 \mathrm{KBq}\right)$ and a good spatial resolution between 1-6 $\mathrm{mm}$, dependent on the construction of the detector and the image reconstruction algorithm. PET is often combined with Computerised Tomography (CT) as a PET-CT scanner and is occasionally combined with magnetic resonance imaging (MRI) as a PET-MRI scanner.

Positron-emitting radioisotopes commonly used in biomedical research include ${ }^{18} \mathrm{~F},{ }^{15} \mathrm{O},{ }^{11} \mathrm{C}$ and ${ }^{13} \mathrm{~N}$ and are usually bound to a biologically-relevant molecules to form a radiopharmaceutical which targets a particular uptake pathway. The most widely used radiopharmaceutical for imaging human patients and research participants is 2-deoxy-2$\left[{ }^{18}\right.$ F]fluoro-D-glucose $\left({ }^{18} \mathrm{FDG}\right)$, which is most commonly used to visualise the metabolism of mammalian cells, such as for the purpose of detecting malignant tumours that take up glucose faster than benign tumours. It therefore follows that ${ }^{18} \mathrm{FDG}$ is a readily available radiopharmaceutical which might accumulate in any cell that has the ability to metabolise glucose, including those in subsurface anaerobic environments. Indeed, anecdotal evidence from PET users suggests that non-sterilized equipment passed through scanners sometimes retains ${ }^{18} \mathrm{FDG}$.

To date, the use of PET in environmental science applications has been limited to a few studies, the majority using non-reactive tracers to image flow paths through sediment and rock systems (e.g. Hoff et al., 1996; Richter et al 2005; Boutchko et al., 2012; Barth et al., 2014; Fernø et al., 2015a; 2015b; Kulenkampff et al., 2015; Viggianni et al., 2015; Kulenkampff et al., 2016; Lippmann-Pipkea et al., 2017). A recent study investigated the 
feasibility of using PET to image a radiotracer labelled bacterial strain Rahella sp Y9602 (Kinsella et al., 2012). In this experiment, mid-log phase 'ideal' cells were emplaced into a column and exposed to $60-115 \mathrm{MBq} \mathrm{ml}^{-1}{ }^{18} \mathrm{FDG}$. Cells sequestered $1.8-7.4 \mathrm{mBq}{ }^{18} \mathrm{~F}$ per cell and cell colonies were clearly visible as bright spots in the column when imaged within 6-8 half-lives of ${ }^{18} \mathrm{~F}$ (half-life 110 minutes). This past work demonstrates that anaerobic glucose metabolism results in sufficient ${ }^{18} \mathrm{~F}$ retention by high cell densities $\left(10^{8}\right.$ colony forming units per ml) of mid-log phase microbial cells grown with nutrient broth.

In this study investigates, for the first time ${ }^{18} \mathrm{FDG}$ interactions with an indigenous sediment microbial community, pre-stimulated with glucose as an electron donor. Flow rates were set to represent those typical of the shallow subsurface $\left(10^{-6} \mathrm{~m} \mathrm{~s}^{-1}\right)$, for example at Sellafield Nuclear Facility where subsurface microbial activity is of interest due to the bioreduction of metal and radionuclide contaminants (Newsome et al., 2014; Thorpe et al., 2017). To further explore ${ }^{18}$ FDG retention onto sediments undergoing microbial reduction, a sediment column with its indigenous microbial population and stimulated with glucose was compared to sterilised control columns of autoclaved sediment and quartz sand.

\section{Experimental Methods}

\section{Experimental set up}

Four cylindrical acrylic columns, A-D, were constructed: length $15 \mathrm{~cm}$ and diameter $10 \mathrm{~cm}$. Columns were supported by circular acrylic plates at each end of the columns, holding them parallel to the axis of the PET-CT scanner (Biograph mCT, Siemens Healthineers, Knoxville, USA) and well within the volume that the PET detector could image optimally at one point in time (50 cm diameter and $20 \mathrm{~cm}$ depth) (Figure 1). The total volume of each column was $1190 \mathrm{~cm}^{3}$ and each contained $\sim 864 \mathrm{~cm}^{3}$ of material plugged at each end with $\sim 323 \mathrm{~cm}^{3}(2$ 
$\mathrm{cm}$ ) of glass fibre wool. Column A contained sediment that was autoclaved prior to the start of the experiment to represent microbially-inactive sediment, column B contained microbially active sediment that was that was pre-amended with $10 \mathrm{mM}$ glucose for 10 days to prime the system for gluclose metabolism prior to PET imaging, column $\mathrm{C}$ contained chemical grade, fine quartz sand (Sigma-Aldrich) and column D contained chemical grade fine quartz sand interspersed with plastic objects as models for solid inclusions and provided a distinctive pattern on CT that acted as reference points for image analysis (Figure 2). Columns were positioned in the scanner (Figure 1) and groundwater flow was induced horizontally at a pump rate of $\sim 5 \times 10^{-6} \mathrm{~m} \mathrm{~s}^{-1}$ achieved with a Watson and Marlow peristaltic pump (5 rpm; $2.05 \mathrm{~mm}$ ID manifold tubing purple-purple).

\section{Sediment}

Sediment in columns A and B represents the geological unit underlying Sellafield nuclear facility, UK and was collected $\sim 2 \mathrm{~km}$ from the site in position: Lat $54^{\circ} 26^{\prime} 30 \mathrm{~N}$, Long $03^{\circ} 28^{\prime} 09 \mathrm{~W}$ adjacent to the Calder River. Sediment was well characterised (Law et al., 2010; Thorpe et al. 2012; Thorpe et al., 2016) and comprised iron rich unconsolidated alluvial flood plain deposits with grain size $0.1-0.5 \mathrm{~mm}$ (fine to medium sand) with a microbial community capable of metabolising a range of electron donors including glucose.

\section{PET - CT scanner and data analysis}

After the 10 day priming period, sediment columns were then transported to the imaging facility and flow was re-established 12 hours prior to the addition of a $10 \mathrm{ml}$ spike of ${ }^{18} \mathrm{FDG}$ at $10 \mathrm{MBq} \mathrm{ml}^{-1}$ (Total $100 \mathrm{MBq}$ ). The radiopharmaceutical ${ }^{18} \mathrm{FDG}$ was imaged using a 
Siemens Biograph mCT PETCT scanner (Jakoby et al., 2011). A CT image was acquired for the four column array and then a series of 18 PET datasets acquired, each for 20 minutes, over a period of 6 hours. Images were reconstructed from each dataset using the Siemens Ultra HD algorithm which enhances image quality by improving contrast and provides a spatial resolution of $2 \mathrm{~mm}$ throughout the acquired volume. Images were analysed using TrueD software on a Siemens Syngo workstation.

\section{S rRNA gene analysis and QPCR}

Following the experiment, 16S rRNA analysis and QPCR were performed on the microbially active sediment to explore the microbial community. Column B was divided into sections and samples were taken from the base of the $2^{\text {nd }}$ quarter, the middle of the $3^{\text {rd }}$ quarter and the top of the $4^{\text {th }}$ quarter. Sequencing of PCR amplicons of $16 \mathrm{~S}$ rRNA was conducted with the Illumina MiSeq platform (Illumina, San Diego, CA, USA) targeting the V4 hyper variable regions (forward primer, 515F, 5'-GTGYCAGCMGCCGCGGTAA-3'; reverse primer, 806R, 5'-GGACTACHVGGGTWTCTAAT-3') for $2 \times 150$-bp paired-end sequencing (Illumina) (Caporaso et al., 2011; Caporaso et al., 2012). PCR amplification was performed using Roche FastStart High Fidelity PCR System (Roche Diagnostics Ltd, Burgess Hill, UK) in 50 $\mu 1$ reactions under the following conditions: initial denaturation at $95^{\circ} \mathrm{C}$ for $2 \mathrm{~min}$, followed by 36 cycles of $95^{\circ} \mathrm{C}$ for $30 \mathrm{~s}, 55^{\circ} \mathrm{C}$ for $30 \mathrm{~s}, 72^{\circ} \mathrm{C}$ for $1 \mathrm{~min}$, and a final extension step of $5 \mathrm{~min}$

at $72^{\circ} \mathrm{C}$. The PCR products were purified and normalised to $\sim 20 \mathrm{ng}$ each using the SequalPrep Normalization Kit (Fisher Scientific, Loughborough, UK). The PCR amplicons from all samples were pooled in equimolar ratios. The run was performed using a $4 \mathrm{pM}$ sample library spiked with 4pM PhiX to a final concentration of $10 \%$ following the method of Schloss and Kozich (Kozich et al., 2013). 
Raw sequences were divided into samples by barcodes (up to one mismatch was permitted) using a sequencing pipeline. Quality control and trimming was performed using Cutadapt (Martin, 2011), FastQC, and Sickle (Joshi and Fass, 2011). MiSeq error correction was performed using SPADes (Nurk et al., 2013). Forward and reverse reads were incorporated into full-length sequences with Pandaseq (Masella et al., 2012). Chimeras were removed using ChimeraSlayer (Haas et al., 2011), and OTU's were generated with UPARSE (Edgar, 2013). OTUs were classified by Usearch (Edgar et al., 2010) at the 97\% similarity level, and singletons were removed. Rarefaction analysis was conducted using the original detected OTUs in Qiime (Caporoso et al., 2010). The taxonomic assignment was performed by the RDP classifier (Wang et al., 2007).

\section{Standard Curve and Quantitative PCR Analysis}

A serial dilution series was performed using a gBlock double stranded DNA gene fragment (Integrated DNA Technologies, Leuven, Belgium) covering nucleotide positions 1-570 of the 16s rRNA gene from species Telluria mixta DSM 4832. The standard curve for the QPCR reaction was created by plotting the $\mathrm{C}_{\mathrm{T}}$ (Cycle threshold) values of the dilution series against the $\log$ input of DNA template. Concentrations ranging from $525 \mathrm{fg}_{\mu \mathrm{l}^{-1}}$ to $0.525 \mathrm{fg}^{-1} \mathrm{l}^{-1}$ were used to generate the standard curve.

PCR amplification was performed using Brilliant II SYBR Green QPCR Master Mix (Agilent Technologies LDA UK Limited, Stockport, U.K) in a $25 \mu 1$ final volume containing $2 \mu 1$ of sample DNA, $0.15 \mu \mathrm{M}$ of each primer and $12.5 \mu \mathrm{l}$ of QPCR SYBR Green Master Mix. All the amplifications were carried out in optical grade QPCR tubes on a MX3000P QPCR system with an initial step of $94^{\circ} \mathrm{C}$ for 10 minutes followed by 30 cycles of $94^{\circ} \mathrm{C}$ for 30 seconds, $50^{\circ} \mathrm{C}$ for 30 seconds, $72^{\circ} \mathrm{C}$ for 45 seconds and a dissociation curve was run between $94^{\circ} \mathrm{C}$ and 
$50^{\circ} \mathrm{C}$ to check primer specificity. Cycle threshold $\left(\mathrm{C}_{\mathrm{T}}\right)$ was determined automatically by the instrument. All samples were analysed in triplicate and the $\mathrm{r}^{2}$ value was 0.998 .

\section{Results}

Transport of ${ }^{18}$ FDG through all four columns was successfully imaged over 6 hours (360 minutes) using PET scans taken at 20-minute intervals and spatially registered to the initial CT scan. The concentration of ${ }^{18} \mathrm{FDG}$ in $\mathrm{Bq} \mathrm{ml}^{-1}$ was calculated for each 20 -minute timeframe for each column as a whole and for each column when it was divided into four sections. This allowed imaging of the ${ }^{18}$ FDG spatial distribution through time. Over the six hours of image acquisition, the spike progressed through the first three quarters of each column with the main body of the plume still present in the fourth quarter at the experiment end point (Figures 3 and 4).

The first quarter $(0-4 \mathrm{~cm})$ of each sediment packed column contained a glass wool plug and a layer of sand to homogenize flow and reduce preferential flow paths. As a result, flow through each column in the first quarter was broadly comparable (Figure 4A) showing no significant difference between the two sediment packed columns (A and B) and the two sand packed columns (C and D) over the first 100 minutes (Figure 4).

In the second quarter $(4-8 \mathrm{~cm})$, the different column media had different ${ }^{18} \mathrm{FDG}$ imaging responses with Column A, containing sterile sediment, Column B, microbially active sediment, Column C, quartz sand, and Column D, quartz sand with plastic objects in, retarding the flow of ${ }^{18}$ FDG by different amounts (Figure 4). Analysis of the second quarter, which was not influenced by the glass wool plug, revealed conservative transport in columns A, C and D (Figure 4) with $<2 \%$ of the spike remaining after 360 minutes. By contrast in the microbially active Column $\mathrm{B}, 13 \%$ of the ${ }^{18} \mathrm{FDG}$ spike $(\sim 13 \mathrm{MBq})$ was retained in the second 
quarter zone over the duration of the experiment on $300 \mathrm{~g}$ of sediment giving an ${ }^{18} \mathrm{~F}$ retention of $\sim 50 \mathrm{kBq} \mathrm{cm}{ }^{3}$ (Table 1; Figure 4).

Analysis of the third quarter $(8-12 \mathrm{~cm})$ showed that the majority of the spike passed through Columns A - D within six hours, however, the tail end of the plume $\sim 10 \%$ was detectable in all columns after 360 minutes. Consequently, it was not possible to confirm exactly what percentage of the spike remains within this quarter as a result of uptake to sediments on the columns. However, in column B, a higher concentration, $27 \%$ of the spike, was detected compared to the $\sim 10 \%$ remaining in columns $\mathrm{A}, \mathrm{B}$ and $\mathrm{C}$.

At the experiment end point, 360 minutes, the spike had reached the end of the column but the centre of the plume was still passing through the $4^{\text {th }}$ quarter.

\begin{tabular}{|l|l|l|c|}
\hline Column & Description & $\begin{array}{l}{ }^{18} \mathbf{F D G} \\
\text { added }\end{array}$ & $\begin{array}{c}\text { \% of spike remaining in } \mathbf{3 0 0} \mathbf{~ c m}^{3} \text { of column } \\
\text { material at the experiment end }\end{array}$ \\
\hline $\mathrm{A}$ & $\begin{array}{l}\text { Sterilized } \\
\text { sediment }\end{array}$ & $100 \mathrm{MBq}$ & $2 \%$ \\
\hline $\mathrm{B}$ & $\begin{array}{l}\text { Microbially active } \\
\text { sediment }\end{array}$ & $100 \mathrm{MBq}$ & $13 \%$ \\
\hline $\mathrm{C}$ & Quartz sand & $100 \mathrm{MBq}$ & $1 \%$ \\
\hline $\mathrm{D}$ & $\begin{array}{l}\text { Quartz sand } \\
\text { reference column }\end{array}$ & $100 \mathrm{MBq}$ & $1 \%$ \\
\hline
\end{tabular}

Table 1: summary of four columns and the activity (decay corrected and expressed as a of the original spike) present associated with the second quarter $\left(300 \mathrm{~cm}^{3}\right)$ at the experiment end point (360 minutes).

Imaging showed the ${ }^{18}$ FDG spike passed completely through the first and second quarter of each column. However, we can use the activity measured in the second quarter to assess ${ }^{18}$ FDG uptake across the different column treatments as this quarter was entirely made up of column packing material (sediment or sand) with no influence from the glass wool plug. Table 1 shows the results obtained, after decay correction, from the second quarter and highlights significant uptake by the microbially active sediment compared to the other columns. This confirms that ${ }^{18}$ FDG did not react with sediment minerals or residual organic 
matter due to the extremely low retention on column A (2\%), sediment sterilized by autoclave, that was similar to retention on pure quartz sand. Retention in the order of $1-2 \%$ may be due to ${ }^{18} \mathrm{FDG}$ collection in unconnected pore space within the column and/or to background error on the PET scanner. Not unexpectedly the spike flowed more slowly through the sediment packed columns (A and B) than through the homogeneous quartz sand packed columns (C and D) but this retardation can be attributed to flow dynamics rather than to chemical retardation. This study concludes that sequestration of ${ }^{18}$ FDG observed in column $\mathrm{B}$, the microbially active column was due to the uptake and labelling of ${ }^{18} \mathrm{FDG}$ by the metabolically-active microbial cells.

\section{Microbial community characterisation}

16S rRNA gene analysis of the sediment in column B, where glucose was added for a week prior to ${ }^{18} \mathrm{FDG}$ addition to stimulate the in-situ community, confirmed a change in the observed microbial community towards glucose metabolising organisms (Figure 5; Supplementary Information Table 1). The sediment prior to glucose amendment comprised a varied microbial community with $70 \%$ identifiable species from the Acidobacteria, Gammaproeobacteria and Alphaproteobacteria classes (Figure 5; Thorpe et al., 2012). Following glucose amendment, close relatives to known glucose metabolising species made up $>40 \%$ of the clone library and included: Actimicrobium antarcticum, Paludibacterium yongneupense (strain 5YN8-15), Clostridium aciditolerans (strain JW/YJL-B3), Clostridium bowmanii (strain DSM 14206), Clostridium arbusti (strain SL206), Clostridium magnum (strain DSM 2767), Clostridium saccharobutylicum strain (NCP 262), Tolumonas auensis (DSM 9187 / TA4), Propionispira paucivorans strain (DSM 20756), and Pelosinus fermentans (DSM 17108) (Supplementary Information Table 1) (Shelobolina et al., 2007; 
Spring et al., 2003; Schlink, 1984, Liu et al., 2014; Ueki et al., 2014; Fischer-Romero et al., 1996; Keis et al., 2001; Jung et al., 2010; Kwon et al., 2008; Kim et al., 2011; Lee et al., 2007). Three samples were taken at regular intervals up to the column, and analysis confirmed a similar microbial community over the $16 \mathrm{~cm}$ of sediment (Figure 5).

QPCR results showed between $10^{6}$ and $10^{7}$ copies per gram (Supporting information: Table 2) leading to an estimated cell density lower than that of the previous experiment using the pre-grown isolate Rahnella sp. Y9602 where a cell density of $10^{8}$ cells per $\mathrm{cm}^{3}$ was estimated and where $75 \mathrm{kBq} \mathrm{cm}{ }^{3}$ was retained (Kinsella et al., 2012). Bacteria typically yield between 1-15 16S rRNA copies per cell (Větrovský and Baldrian, 2013) and therefore, cell density in Column B can be roughly estimated at $10^{5}-10^{6}$ cells per gram. Although the cell density in this current study examining natural sediments was lower than the model system explored by

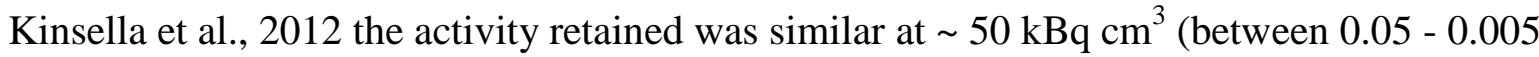
$\mathrm{Bq}$ per cell). This was sufficient activity to be detectable throughout the 6 hour imaging period despite the 110 minute half-life of ${ }^{18} \mathrm{~F}$.

\section{Conclusions}

This study has demonstrated the feasibility of using ${ }^{18}$ FDG labelling coupled to PET imaging to image microbial metabolism and visualise the location of metabolising cells in a complex natural sediment system. The study confirms that the metabolic rate of this in-situ community is sufficient uptake ${ }^{18} \mathrm{FDG}$ at detectable levels at flow rates of $10^{-6} \mathrm{~m} \mathrm{~s}^{-1}$, cell densities of $10^{5}-10^{6}$ cells per gram and ${ }^{18}$ FDG concentration of $\sim 10^{-12}$ mol dm ${ }^{-1}$ (accounting for a 200 fold dilution of the $1.5 \times 10^{-10} \mathrm{~mol} \mathrm{dm}{ }^{-1}$ spike). This technique could be optimised to visualize microbial metabolism in a range of natural and engineered environments, including sediment 
pore spaces and rock fractures or in anthropogenic systems such as pipework and machine interiors.

\section{Acknowledgements}

The authors would like to acknowledge the support of the Manchester Royal Infirmary, Nuclear Medicine Department, in allowing this research to be conducted alongside normal patient appointments.

Funding: This research was funded by the University of Manchester through an internal seedcorn grant award for young researchers and supported through an EPSRC Knowledge Transfer Grant on management of radioactively contaminated land.

\section{References}

Barth, T., Ludwig, M., Kulenkampff, J., Gründig, M., Franke, K., Lippmann-Pipke, J., Hampel, U., (2014). Positron emission tomography in pebble beds. Part 1: Liquid particle deposition. Nuclear Engineering and Design, 267, 218-226.

DOI:10.1016/j.nucengdes.2013.03.011

Boutchko, R., Rayz, V.L., Vandehey, N.T., O’Neil, J.P., Budinger, T.F., Nico, P.S., Druhan, J.L., Saloner, D.A., Gullberg, G.T., Moses, W.W., (2012). Imaging and modelling of flow in porous media using clinical nuclear emission tomography systems and computational fluid dynamics. Journal of Applied Geophysics, 76, 74-81. DOI:10.1016/j.jappgeo.2011.10.003

Caporaso, J. G., Lauber, C.L., Walters, W.A., Berg-lyons, D., Lozupone, C.A., Turnbaugh, P.J., Fierer, N., Knight, R., (2011). Global patterns of 16S rRNA diversity at a depth of 
millions of sequences per sample. Proceedings of the National Academy of Sciences $\mathbf{1 0 8}$ (Supplement 1): 4516-4522. DOI:10.1073/pnas.1000080107

Caporaso, J. G., Lauber, C.L., Walters, W.A., Berg-lyons, D., Huntley, J., Fierer, N., Owens, S.M., Betley, J., Fraser, L., Bauer, M., Gormley, N., Gilbert, J.A., Smith, G., Knight, R., (2012). Ultra-high-throughput microbial community analysis on the Illumina HiSeq and MiSeq platforms. ISME J 6 (8): 1621-1624. DOI:10.1038/ismej.2012.8

Caporaso, J. G., Kuczynski, J., Stombaugh, J., Bittinger, K., Bushman, F.D., Costello, E.K., Fierer, N., Gonzalez Pena, A., Goodrich, J.K., Gordon, J.I., Huttley, G.A., Kelley, S.T., Knights, D., Koenig, J.E., Ley, R.E., Lozupone, C.A., McDonald, D., Muegge, B.D., Pirrung, M., Reeder, J., Sevinsky, J.R., Turnbaugh, P.J., Walters, W.A., Widmann, J., Yatsunenko, T., Zaneveld, J., Knight, R., (2010). QIIME allows analysis of high-throughput community sequencing data. Nature Methods, 7(5): 335-336. DOI:10.1038/nmeth.f.303

Edgar, R. C. (2010). Search and clustering orders of magnitude faster than BLAST. Bioinformatics 26 (19): 2460-2461. DOI:10.1093/bioinformatics/btq461

Edgar, R. C. (2013). UPARSE: highly accurate OTU sequences from microbial amplicon reads. Nature Methods, 10 (10): 996-998. DOI:10.1038/nmeth.2604

Fernø, M.A.,Gauteplass, J., Hauge, L.P., Abell, G.E., Adamsen, T.C.H., Graue, A., (2015a). Combined positron emission tomography and computed tomography to visualize and quantify fluid flow in sedimentary rocks, Water Resource Research, 51 (9), 7811-7819. DOI:10.1002/2015WR017130

Fernø, M.A., Hauge, L.P., Uno Rognmo, A., Gauteplass, J., Graue, A., (2015b). Flow visualization of $\mathrm{CO}_{2}$ in tight shale formations at reservoir conditions. Geophysical Research Letters, 42 (18), 7414-7419. DOI:10.1002/2015GL065100 
Fisher-Romero, C., Tindall, B.J., Jüttner, F., (1996). Tolumonas auensis gen. nov., sp. nov., a Toluene-Producing Bacterium from Anoxic Sediments of a Freshwater Lake. International Journal of Systematic and Evolutionary Microbiology 46 (1): 183-188.

DOI:10.1099/00207713-46-1-183

Haas, B. J., Gevers, D., Earl, A.M., Felgarden, M., Ward, D.V., Giannoukos, G., Ciulla, D., Tabbaa, D., Highlander, S.K., Sodergren, E., Methé, B., DeSantis, T.Z., Human Microbiome Consortium, Petrosino, J.F., Knight, R., Birren, B.W., (2011). Chimeric 16S rRNA sequence formation and detection in Sanger and 454-pyrosequenced PCR amplicons. Genome Research 21 (3): 494-504. DOI:10.1101/gr.112730.110

Hoff, W.D.,Wilson, M.A., Benton, D.M., Hawkesworth, M.R., Parker, D.J., Flowles, P. (1996). The use of positron emission tomography to monitor unsaturated water flow within porous construction materials. Journal of Materials Science Letters. 15. 1101-1104. DOI:10.1007/BF00539949.

Jakoby, B.W., Bercier, Y., Conti, M., Casey, M.E., Bendriem, B., Townsend, D.W. (2011). Physical and clinical performance of the mCT time-of-flight PET/CT scanner. Physics in Medicine and Biology, 56, 2375-2389. DOI:10.1088/0031-9155/56/8/004

Joshi, N.A., Fass, J.N. (2011). Sickle: A sliding-window, adaptive, quality-based trimming tool for FastQ files (Version 1.33) [Software]. Available at https://github.com/najoshi/sickle. Jung, M. Y., Park, I.S., Kim, W., Paek, W.K., Chang, Y.H., (2010). Clostridium arbusti sp. nov., an anaerobic bacterium isolated from pear orchard soil. International Journal of Systematic and Evolutionary Microbiology, 60 (9), 2231-2235. DOI: 10.1099/ijs.0.013953-0 
Keis, S., Shaheen, R., Jones, D.T., (2001). Emended descriptions of Clostridium acetobutylicum and Clostridium beijerinckii, and descriptions of Clostridium saccharoperbutylacetonicum sp. nov. and Clostridium saccharobutylicum sp. nov. International Journal of Systematic and Evolutionary Microbiology, 51 (6), 2095-2103. DOI: $10.1099 / 00207713-51-6-2095$

Kim E., Jeong H.-J., Lee Y., Moon E., Cho J.-C., Lee H. and Hong S., (2011). Actimicrobium antarcticum gen. nov., sp. nov., of the Family Oxalobacteraceae, Isolated from Antarctic Coastal Seawater. Current Microbiology, 63, 213-217. DOI:10.1007/s00284011-9962-9

Kinsella, K., Schlver, D.J., Fowler, J.S., Martinez, R.J., Sobecky, P.A., (2012). Evaluation of positron emission tomography as a method to visualize subsurface microbial processes. Journal of Hazardous Materials, 213-214, 498-501. DOI:10.1016/j.jhazmat.2012.01.037

Kozich, J. J., Westcott, S.L., Baxter, N.T., Highlander, S.K., Schloss, P.D., (2013).

Development of a Dual-Index Sequencing Strategy and Curation Pipeline for Analyzing Amplicon Sequence Data on the MiSeq Illumina Sequencing Platform. Applied and Environmental Microbiology, 79 (17), 5112-5120. Supplemental Material.

DOI:10.1128/AEM.01043-13

Kulenkampff, J., Gründig, M., Zakhunini, A., Gerasch, R., Lippmann-Pipke, J., (2015). Process tomography of diffusion, using PET, to evaluate anisotropy and heterogeneity. Clay Minerals, 50 (3), 369-375. DOI:10.1180/claymin.2015.050.3.09

Kulenkampff, J., Zakhunini, A., Gründig, M., Lippmann-Pipke, J., (2016). Quantitative experimental monitoring of molecular diffusion in clay with positron emission tomography. Solid Earth, 7, 1207-1215. DOI:10.5194/se-7-1207-2016 
Kwon, S.-W., Kim, B.Y., Kim, W.G., Yoo, K.H., Yoo, S.H., Son, J.A., Weon, H.Y., (2008).

Paludibacterium yongneupense gen. nov., sp. nov., isolated from a wetland, Yongneup, in Korea. International Journal of Systematic and Evolutionary Microbiology 58 (1), 190-194. DOI:10.1099/ijs.0.64831-0

Law, G.T.W., Geissler, A., Boothman, C., Burke, I.T., Livens, F.R., Lloyd, J.R., Morris, K., (2010). Role of nitrate in conditioning aquifer sediments for technetium bioreduction.

Environmental. Science \& Technology. 44, 150-15. DOI:10.1021/es9010866.

Lee, Y.-J., Romanek, C.S., Wiegel, J., (2007). Clostridium aciditolerans sp. nov., an acidtolerant spore-forming anaerobic bacterium from constructed wetland sediment. International Journal of Systematic and Evolutionary Microbiology, 57(2), 311-315.

DOI:10.1099/ijs.0.64583-0

Lippmann-Pipkea, J., Gerascha, R., Schikoraa, J., Kulenkampff, J., (2017). Benchmarking PET for geoscientific applications: 3D quantitative diffusion coefficient determination in clay rock. Computers \& Geosciences, 101, 21-27. DOI:10.1016/j.cageo.2017.01.002

Liu, C., Huang, D., Liu, L., Zhang, J., Deng, Y., Chen, L., Zhang, W., Wu, Z., Fan, A., Lai, D., Dai, L., (2014). Clostridium swellfunianum sp. nov., a novel anaerobic bacterium isolated from the pit mud of Chinese Luzhou-flavor liquor production. Antonie Van Leeuwenhoek 106 (4), 817-825. DOI:10.1007/s10482-014-0251-z

Martin, M. (2011). Cutadapt removes adapter sequences from high-throughput sequencing reads. EMBnet Journal, 17 (1). DOI:10.14806/ej.17.1.200

Newsome, L., Morris, K., Lloyd, J.R. (2014). The biogeochemistry and bioremediation of uranium and other priority radionuclides. Chemical Geology, 363, 164-184; DOI 10.1016/j.chemgeo.2013.10.034. 
Nurk, S., Bankevich, A., Antipov, D., Gurevich, A., Korobeynikov, A., Lapidus, A., Prjibelsky, A., Pyshkin, A., Sirotkin, A., Sirotkin, Y., Stepanauskas, R., McLean, J., Lasken, R., Clingenpeel, S.R., Woyke, T., Tesler, G., Alekseyev, M.A., Pevzner, P.A. (2013). Assembling Genomes and Mini-metagenomes from Highly Chimeric Reads. Research in Computational Molecular Biology: 17th Annual International Conference, RECOMB 2013, Beijing, China, April 7-10, 2013. Proceedings. In M. Deng, R. Jiang, F. Sun and X. Zhang. Berlin, Heidelberg, Springer Berlin Heidelberg: 158-170. DOI:10.1007/978-3-642-37195$0 \_13$

Masella, A. P., Bartram, A.K., Truszkowski, J.M., Brown, D.G., Neufeld, J.D., (2012). PANDAseq: paired-end assembler for illumina sequences. BMC Bioinformatics, 13 (1), 1-7. DOI:10.1186/1471-2105-13-31

Schink, B. (1984). Clostridium magnum sp. nov., a non-autotrophic homoacetogenic bacterium. Archives of Microbiology, 137(3), 250-255. DOI:10.1007/BF00414553

Shelobolina E.S., Nevin K.P., Blakeney-Hayward J.D., Johnsen C.V., Plaia T.W., Krader P., Woodard T., Holmes D.E., VanPraagh C.G., Lovley D.R., (2007). Geobacter pickeringii sp. nov., Geobacter argillaceus sp. nov. and Pelosinus fermentans gen. nov., sp. nov., isolated from subsurface kaolin lenses. International Journal of Systematic and Evolutionary Microbiology, 57, 126-135. DOI:10.1099/ijs.0.64221-0

Spring, S., Merkhoffer, B., Weiss, N., Kroppenstedt, R.M., Hippe, H., Stackebrandt, E. (2003). Characterization of novel psychrophilic clostridia from an Antarctic microbial mat: description of Clostridium frigoris sp. nov., Clostridium lacusfryxellense sp. nov., Clostridium bowmanii sp. nov and Clostridium psychrophilum sp. nov and reclassification of Clostridium laramiense as Clostridium estertheticum subsp. laramiense subsp. nov. 
International Journal of Systematic and Evolutionary Microbiology, 53(4), 1019-1029. DOI:10.1099/ijs.0.02554-0

Thorpe, C.L., Law, G.T.W., Boothman, C., Lloyd, J.R., Burke, I.T., Morris, K., (2012) Synergistic effect of high nitrate concentrations on sediment bioreduction. Geomicrobiol. Journal, 29, 484-493. DOI:10.1080/01490451.2011.581332

Thorpe, C.L., Lloyd, J.R., Law, G.T.W., Williams, H.A., Atherton, N., Cruickshank, J.H., Morris, K., (2016). Retention of 99mTc at ultra-trace levels in flowing column experiments insights into bioreduction and biomineralization for remediation at nuclear facilities. Geomicrobiol. Journal. 33, 199-205. DOI:10.1080/01490451.2015.1067656.

Thorpe, C.L., Law, G.T.W., Lloyd, J.R., Williams, H.A., Atherton, N., Morris, K., (2017). Quantifying technetium and strontium bioremediation potential in flowing sediment columns. Environmental science \& technology, 51 (21), 12104-12113. DOI: 10.1021/acs.est.7b02652

Ueki, A., Watanabe, M., Ohtaki, Y., Kaku, N., Ueki, K., (2014). Description of Propionispira arcuata sp. nov., isolated from a methanogenic reactor of cattle waste, reclassification of Zymophilus raffinosivorans and Zymophilus paucivorans as Propionispira raffinosivorans comb. nov. and Propionispira paucivorans comb. nov. and emended description of the genus Propionispira. International Journal of Systematic and Evolutionary Microbiology. 64 (10), 3571-3577. DOI:10.1099/ijs.0.063875-0

Větrovský, T., Baldrian, P., (2013). The variability of the 16S rRNA gene in bacterial genomes and its consequences for bacterial community analyses. PLOS, published February 27. DOI:10.1371/journal.pone.0057923 
Viggiani, G., Andò, E., Takano, D., Santamarina, J.C., (2015). Laboratory X-ray

tomography: A valuable experimental tool for revealing processes in soils. Geotechnical Testing Journal, 38, 61-71. DOI:10.1520/GTJ20140060

Wang, Q., Garrity, G.M., Tiedje, J.M., Cole, J.R., (2007). Naïve Bayesian Classifier for Rapid Assignment of rRNA Sequences into the New Bacterial Taxonomy. Applied and Environmental Microbiology 73(16), 5261-5267. DOI:10.1128/AEM.00062-07

\section{Figure captions}

Figure 1: Set up of columns in an acrylic frame to make best use of the space available in the PET-CT scanner.

Figure 2: CT image showing a cross section through of the four columns in place in the PET scanner. Dots represent screws holding columns in an acrylic frame. Columns packed with A) sterilised sediment, B) microbially active sediment, C) fine sand and D) fine sand with items to disrupt groundwater flow.

Figure 3: Fused PET (fire colour scale) and CT (grey colour scale) images showing ${ }^{18}$ FDG transport at 1, 3 and 6 hours through columns A) sterilized sediment, B) microbially active sediment, C) quartz sand and D) quartz sand reference column.

Figure 4: Percentage of spike present in each quarter against time. The $1^{\text {st }}$ quarter being the base of the column at which the spike enters and the $4^{\text {th }}$ quarter being the top of the column where the spike exits. The blue line represents column A (sterilized sediment), the red line represents column B (microbially active sediment), the purple line represents column C (quartz sand) and the green line represents column D (the reference column). 
Figure 5: Microbial community analysis of three sample points in the lower (bottom of $2^{\text {nd }}$ quarter), middle (middle of third quarter) and upper (top of fourth quarter) of the column.

\section{Figure 1}

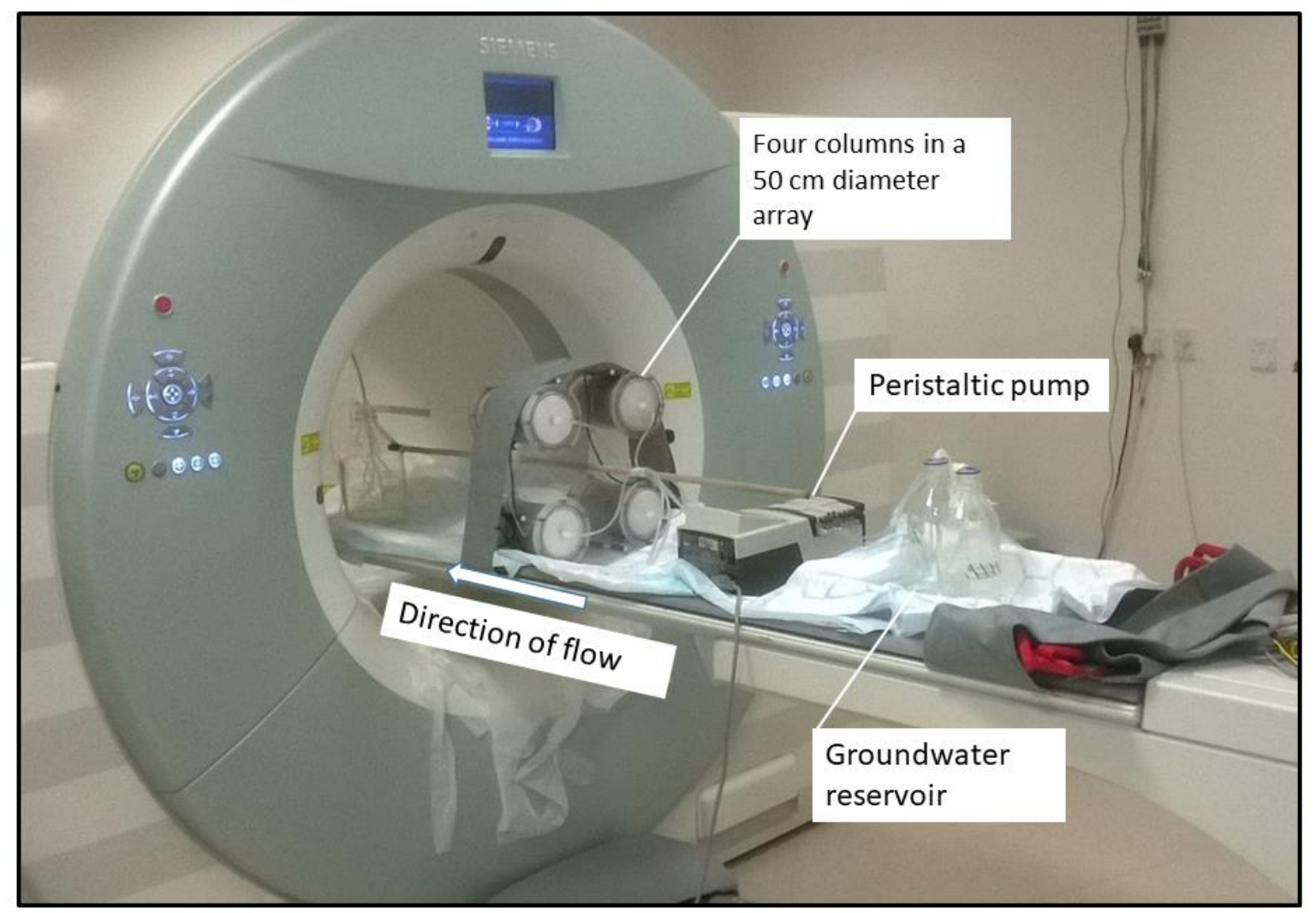


Figure 2

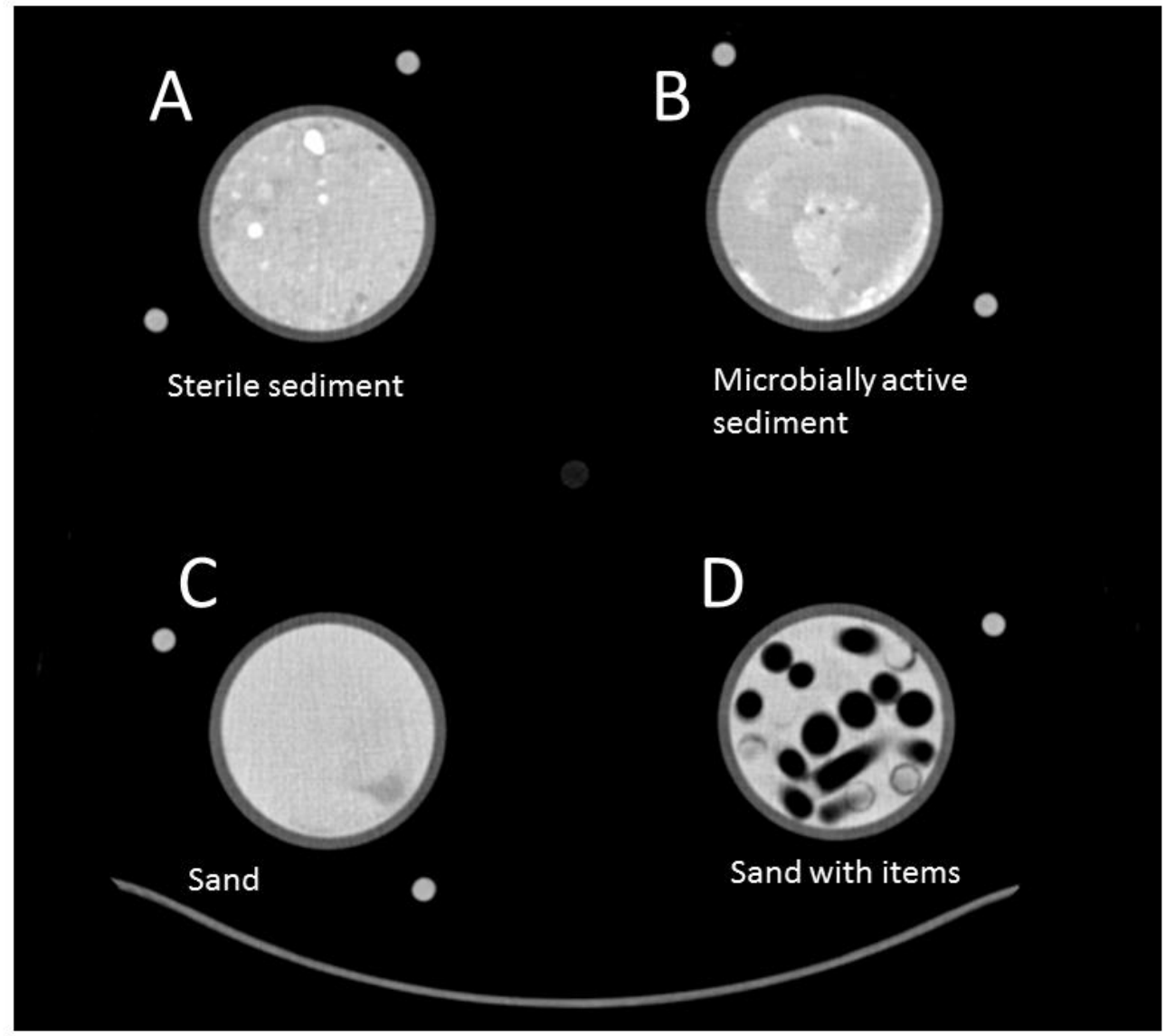


Figure 3

\section{Start of the experiment $\mathrm{T}=1$ hour}

Middle of the experiment $\mathrm{T}=3$ hour
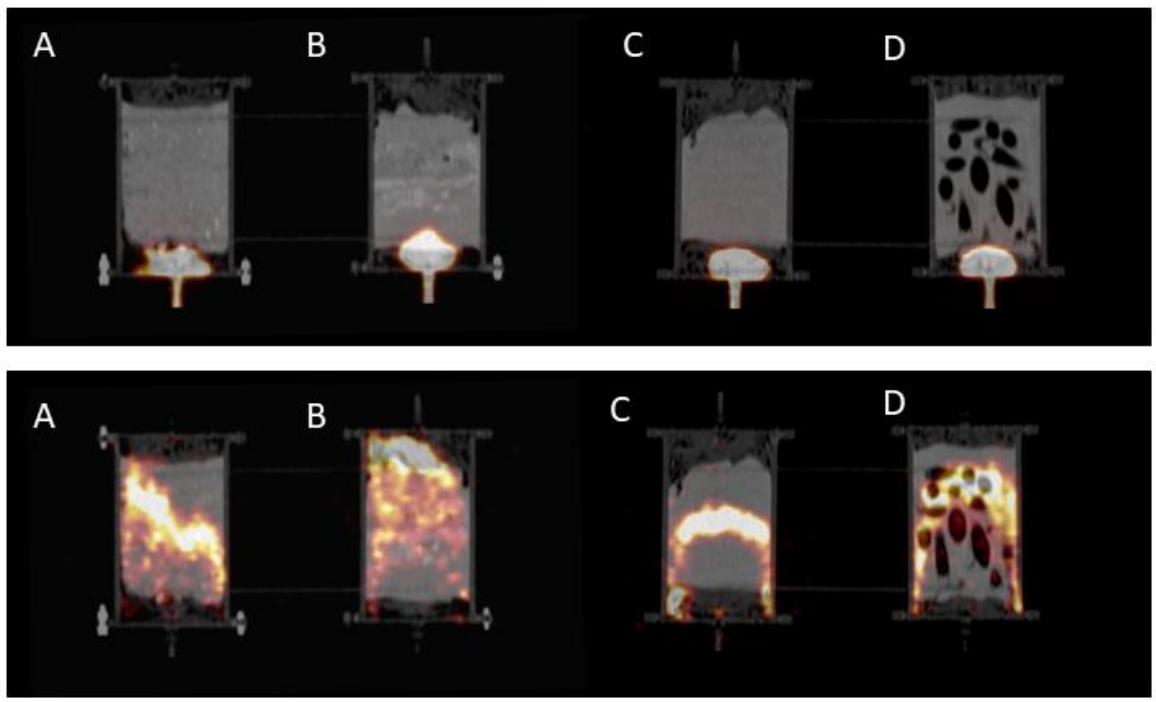

End of the experiment $T=6$ hour

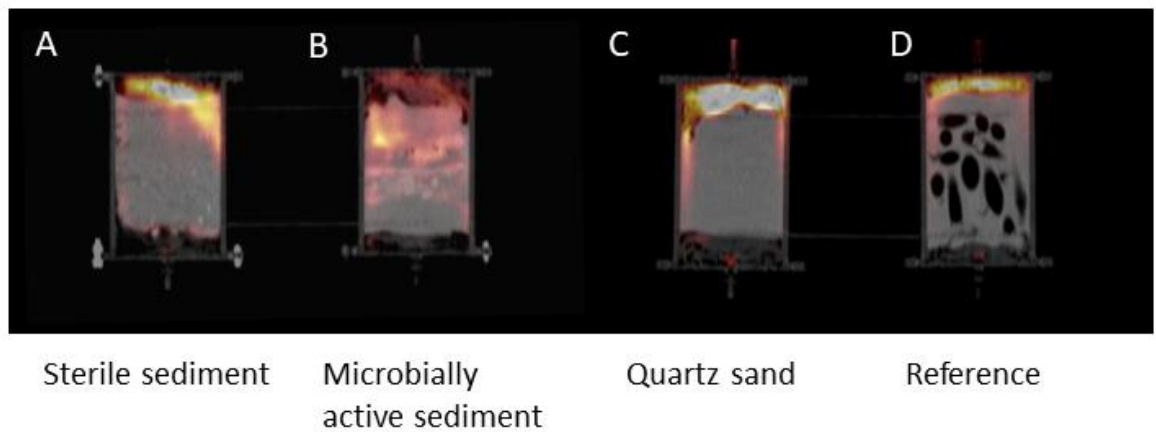


Figure 4
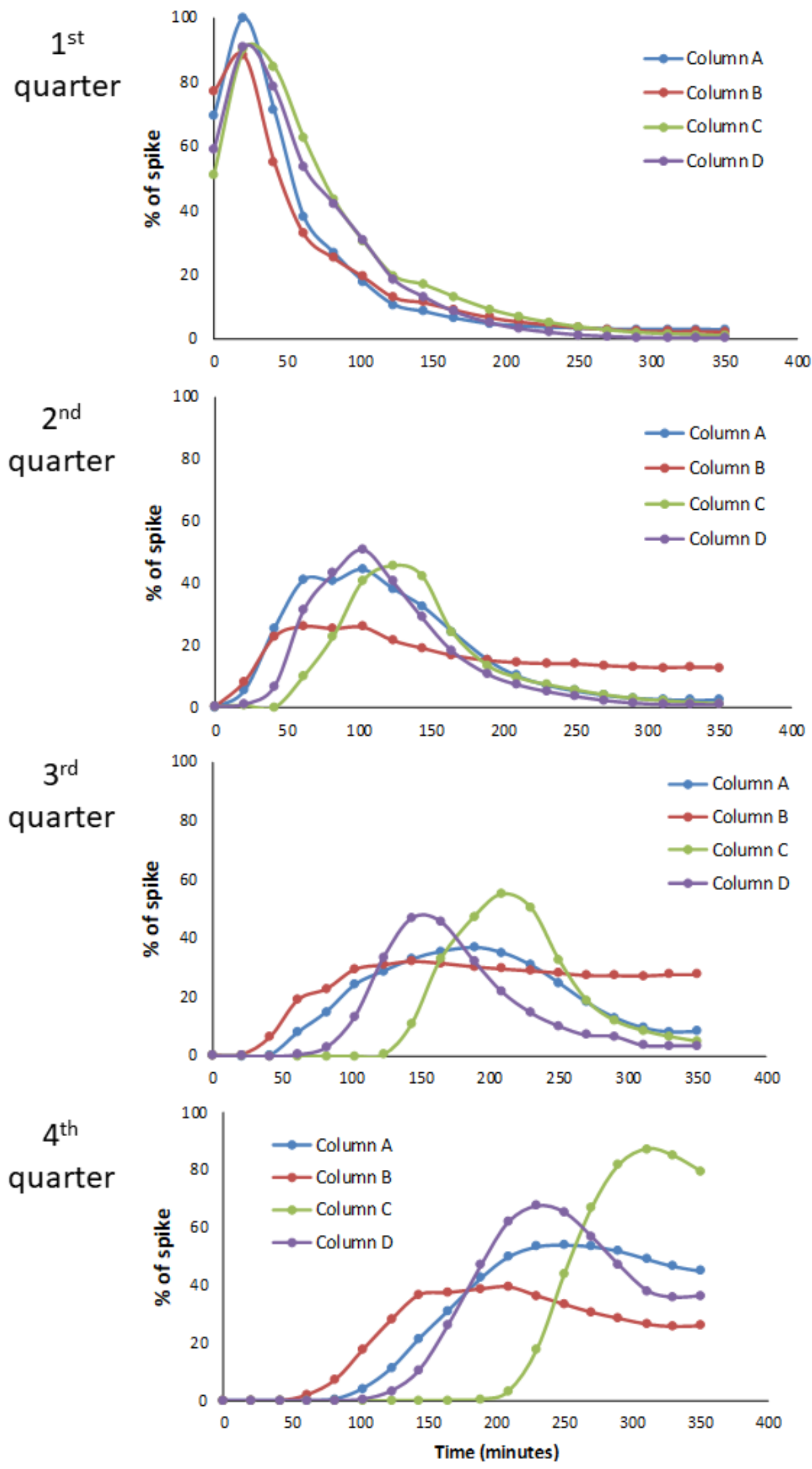
Figure 5

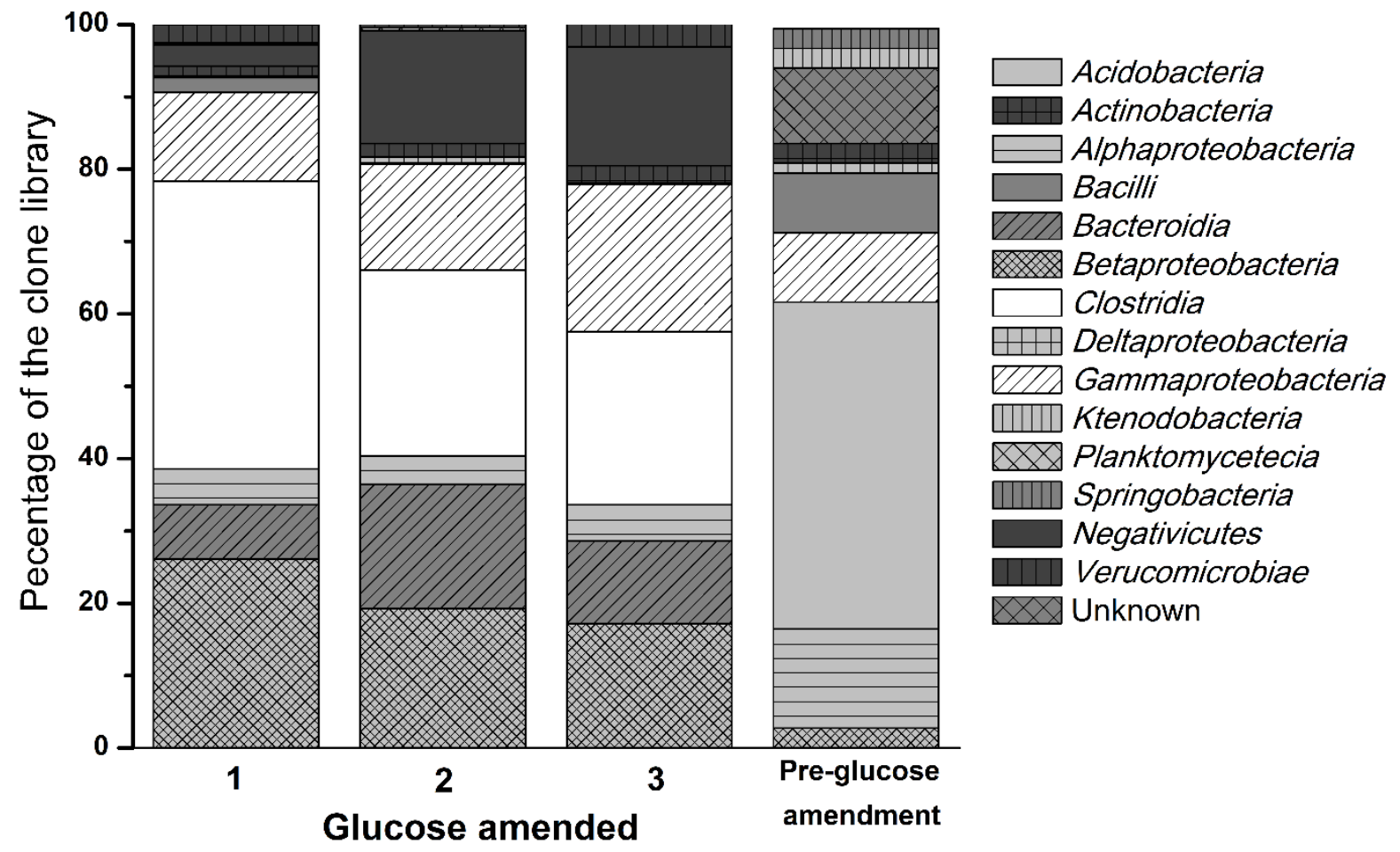

